\title{
Unethical practices among physics education teachers in post primary schools and tertiary institutions
}

\author{
Theresa, Ugonwa Okafor
}

\begin{abstract}
Department of Science Education, Chukwuemeka Odumegwu Ojukwa University, PMB 02 Uli, Anambra State, Nigeria.
\end{abstract}
E-mail: teresaokafor@gmail.com. Tel: +2348063722257.

Accepted $4^{\text {th }}$ April, 2019.

\begin{abstract}
The physics teachers as well as the physics students are always cautioned against engaging in practices that are against the university's code of conduct. Despite this, some physics teachers in Anambra State still find means of cutting corners by engaging in acts that are unethical to the secondary schools. Indiscipline among physics students in post primary institutions in Anambra state can be encouraged by unethical practices among physics teachers. Physics education goals as spelled in the National Policy of Education can hardly be achieved without firm obedience to set down rules essential for the general welfare of the society and on this ground this paper critically x-rayed the effect of some unethical practices, such as absenteeism from scheduled lesson/ lecture period, taking undue advantages of physics students, facilitating, aiding, abetting or assessor to examination malpractice and money for marks racketing among physics teachers as the causes of indiscipline in post primary and tertiary Institutions in Anambra State. The paper is of the view that there is need for a holistic reorientation, re-engineering and rebranding of physics education teachers on their professional code of conduct, especially during physics education teachers training and recruitments, if effective quality of physics education is to be achieved in Anambra State. The paper highlights recommendations geared at promoting ethical behaviours in the post-primary and tertiary institutions in Anambra State.
\end{abstract}

Keywords: Unethical practices, physics education teachers, indiscipline.

\section{INTRODUCTION}

Physics Education is the bedrock of national development. No nation can achieve its educational goals without quality physics education provided for its citizenry (Sham, 2014). Therefore, physics education should not only prepare an individual to earn a living, but also to live a creative, human and sensitive life. Achukwu and Ementa (2014) opined that teaching is a noble and respectable profession in the developed counties of the world, it is often described as the mother of all professions such as engineering, law, pharmacy, nursing, medicine and so on. A look of most of the problems facing physics teaching in the recent times in the developing world such as Nigeria, includes the problem of unethical practices of the profession. Education in Nigeria is naturally conceptualized not simply as the medium for cultural transmission but the main vehicle for accelerating individual, community and national development. It is a mechanism through which the society generates the knowledge and skills required for its survival and sustenance. It enriches peoples understanding of themselves and the world. It improves the quality of lives and leads to broad social benefits to individuals and society (Kazeem and Ige, 2010).

Ethics on one hand is one of those concepts that do not lend themselves to a broadly and generally accepted definition. According to Adewunmi (1998) in Kanu and Ursula (2012), what seems to be a conceptual about ethics is that it has to do with what is good or not; what is morally right or wrong. What is acceptable in a Nigerian environment, what is expected or not of a person, etc; ethics connotes the guidelines or rules of conducts by which we aim to live, work and socialize. Ethical behavior as pointed out by Ogunleye (2000) occurs when one acts with equity, fairness, impartiality, and respect the rights of 
others, or simply put, when does what is morally right, whereas unethical behaviours occur when decisions enable an individual or organization to gain at the expense of the larger society. Unethical Practices is universal in all nations of the world and covers all professions; be it Medical, Teaching, Legal or Banking (Johnston, 2000). It is a professional abuse on the supervisor (teacher) towards a subordinate (student) in the teaching profession.

Overtime, unethical practices have affected the fortunes of our educational system in Nigeria especially physics education which is perhaps on its lowest ebb now. The caliber of physics teachers in our post primary schools and tertiary institutions has become a serious concern. Majority of physics teachers produced in colleges of education and universities are not knowledgeable in their physics areas. Some of them had below average performance when they were physics students. Some had far worse grades in teaching physics as a subject. Most physics teachers in post primary schools seem not to have the requisite knowledge, experience and skill to impact to the student. How then do we expect them to suddenly transform into good physics teacher? This is a confirmation of the long dictum that says "nemo dat quod non habet i.e. one cannot give what he hasn't got" (Kanu and Ursula, 2012).

There is a lot of lackadaisical attitude to work by physics teachers in post primary schools which perhaps have led to low students enrolment in physics education in universities and also very low performance in West African Senior Secondary Certificate Examination (WASSCE). They are usually preoccupied with hawking of their wares doing official period, when they eventually settle to teach, they hardly have enough time to cover the syllables. They usually organize 'extra lessons' with its attendant financial implications to make up for lost time.

The implication of this is that they can go at any length to ensure that their candidates perform satisfactorily in these examinations. Due to lack of adequate qualified physics education teachers in post primary schools and tertiary institutions, graduates of other allied disciplines such as engineering, computer science, geology, etc have been ironically recruited to invade the classroom. If the dictum "no education can rise above the quality of its teacher" is true, then the caliber and quality of persons recruited into teaching may not be able to see the nation to the promise land of technological development. Infiltration of the workforce by non-professionals has impacted positively on the level of moral decadence on our educational sector.

Unethical practices could be in form of physical, sexual, psychological and neglect (Olujuwon et al., 2012). The physical abuse involve physical aggression directed towards a student by a school teacher with the deliberate infliction of serious injury, while the sexual involve abusing a student for sexual stimulation, asking a student for sexual favours for passing promotional and WASSCE examination etc. Its effect could result in mental illness, guilt and self-blame, stress, sex disorder and many other psychosocial behavior. Another form of unethical practice among physics education teachers is 'name calling/ridicule', degradation, excessive criticism; withholding communication and routine labeling. All these may lead to poor educational achievement among physics students. This is therefore why Surrey County Council (2012) exerted that unethical practices occur when a professional in any institution or organization takes advantage of his/her student's trust or exploits their vulnerability, or does not act in his or her best interest or fails to keep physics teachers' professional boundaries and ethics and exploitation of the vulnerability of a physics student in an institution. Therefore unethical practices among physics teachers includes abuse in the teaching profession which ranges from having an illicit affair with students, giving undue advantage to students by releasing examination question before the examination date, airing and abating during examination, certificate forgeries, failure to whistle blow on issues that hamper teaching and learning processes of physics (Olujuwon et al., 2012).

In a physics teaching profession, the ethics of the profession places a great responsibility on the physics lecturer to render services and conduct self, according to the books (Shani, 2005). Any physics teachers' activity or behavior that falls short of the code of conduct, could be seen as unethical practice or professional abuse. However unethical practices among physics education in post primary schools and tertiary institution take many shapes and colours but the essential thread that runs through all forms of abuses is a superior conducting himself in an unethical manner towards a subordinate (Ayee, 1997).

The study focuses on unethical practices among physics education teachers which may be displayed in various forms of unethical activities towards their students. These include deliberate negligence of duty, unwholesome demands in form of sexual assault, verbal or physical attack, examination malpractices in terms of awarding high-unmerited scores to favourite student and the release of examination questions prior to the exam date and similar cases in tertiary institution (Olujuwon, 2004). Sex for scores and money money for high grades are negative slogans bandied around in post primary schools and tertiary institutions. Others include: setting physics examination questions out of the course outline, sell of physics handout, plagiarism, undertaking to write project for physics student, non-enforcement of attendant to class, lack of commitment to physics teaching. The implication of unethical practices among physics teacher are equally $\mathrm{x}$-rayed.

Unethical practices or behavior is when one is not conforming to approved standard of the social or professional behaviour. On the other hand, it is about behaviour and ways of thinking, especially in situations 
where our choice can affect the dignity and wellbeing of others. According to Uhlmann et al. (2009), unethical behaviour are acts that violate widely held moral principles (such as honesty or fairness). It should be noted that secondary schools and tertiary institutions where unethnical practices are highly operational cannot produce disciplined and quality physics education students/graduates.

Indiscipline as a thought has proved elusive to define in precise and clear terms. This is because most people have wide divergent views about the concept. Dare et al. in Zubaida (2009) defined discipline in schools as respect for school laws and regulations and maintenance of an established standard of behaviour and implies selfcontrol, restraint, respect for oneself and others. A behaviour that contradicts the above becomes indiscipline. Indiscipline among Physics education students in posts-primary and tertiary institutions of Anambra State has been overtime, an issue of concern for physics educator, policy-makers, and the public opinion in general, owing to the outbreak of aggressiveness and peers, violence within physics teacher/student relationship and vandalism as well.

Amaelo in Achukwu and Emente (2011) opined that indiscipline behaviours are not only offensive (as general opinion does believe) but also defensive as physics students sometimes try to protect his / her image at "infinity" or as a strategy of "maintenance" and "survival" towards physical, psychic and moral rhythms and constraints of school and of the classroom. This explains that methodological practices by physics teachers towards physics students can promote indiscipline among physics students. This is in accordance with Rogers (2003) who states that the child is naturally good, but it is the teacher that corrupts him. He also pointed out that teachers ignore students' problems and complaints whether academic or otherwise. This prepares ground for indiscipline to the physics students,

The Teachers Registration Council of Nigeria (TRCN) was established by Act. No 31 of 1993 to regulate and control the teaching profession. Until 1993 teaching Profession in Nigeria has been regarded a dumping ground for people who desire to have a temporary job while they seek other jobs of their dreams. This was because there was no regulatory agency for membership and practice as the Nigerian Bar Association does for lawyers, Council for Regulation of Engineers in Nigeria (COREN) for engineers and the Nigerian Medical Association for medical doctors. The question of whether teaching is really a profession or not has therefore long been settled with the enactment of the TRCN Act in Nigeria.

This development is expected to bring about transformation of the teaching profession to the possible highest standard. Particularly with respect to professional conduct, the quality of Physics Education programmes, registration and licensing, and the overall status of physics teachers at all levels of the education system. Like any other professions in the world, the teaching profession has its own code of Professional Ethics which indeed is a condition to ensure its self-esteem and integrity. The code provides Physics teachers the frame work of principles to guide them in discharging their obligations towards Physics students, colleagues and community.

From the foregoing, it is expected that the Physics teachers must be guided by her code of ethics as gained guidelines that need to be taken into account, along with other relevant conditions, in the discharge of their duty. Professional ethics is the expected conduct of professionals in carrying out their work. Generally, according to Okpala (2014) it is defined according to laiddown principles of honesty, integrity, transparency, accountability, confidentiality, objectivity, respectfulness, obedience to the law and loyalty in Nigeria, the Teacher's Registrations Council's Code of conduct stipulates standards for physics teachers who are expected to abide by these codes and be truly ethical. True ethics means holding themselves to the highest level of behaviour because of the desire to do so and not of fear of getting caught and punished.

In view of this, there is an absolute need for a profound study to expose to physics teachers as stakeholder in the physics education system, how their actions and inactions have individually and collectively contributed to the collapsing state of physics education in post primary schools and tertiary institutions in Anambra State.

Thus, this study is set out to review some of the unethical practices by physics teachers (wrong doings) that have been associated with encouraging physics students' acts of indiscipline. To address these issues, our discussions focus on the following key areas:

- Discipline and ethical issues in post primary schools and tertiary institutions

- Causes of unethical practices

- Unethical practices at the tertiary level of education

- Implications of unethical practices by physics teachers at the tertiary levels of physics education in Nigerian

- Conclusion

- Recommendation

\section{DISCIPLINE AND ETHICAL ISSUES IN POST PRIMARY SCHOOLS AND TERTIARY INSTITUTIONS}

One of the most serious problems to undermine the provision of quality physics education in secondary schools and tertiary Institutions is that of indiscipline. Due to the great concern shown both by the individual in general and society in particular about the word "discipline", it becomes very necessary to ask why discipline is so much needed in any established organization or group (Achukwu and Ementa, 2014). 
In the post primary schools and tertiary Institutions, the purpose of discipline is to produce physics education students who will be well behaved in the society by differentiating what is good from what is bad and striving to do good for the general welfare of the society. Most educated elites, government, parents and even stakeholders in education recognize the fit that educating physics education students to conform to acceptable rules and regulations of the society is not an easy task and as such, it must be joint efforts of the parents, the Church, the school and the government.

The poor compliance of the code of ethics especially on the parts of physics teachers suggests poor moral character of physics teachers in schools. The poor ethical behaviour of physics teachers has had serious consequences in the profession, and in the moral upbringing of physics students in schools. This is clearly shown in the way of life of most children, which is characterized by lack of respect, dishonesty, impatience etc. the rampant cases of cultism and other delinquent behaviour in schools are traceable to this.

\section{CAUSES OF UNETHICAL PRACTICES}

According to Ajayi and Adeniji (2009), the major cause of unethical practices amongst physics education teachers in our education system could be attributed to the following factors:

The attitude of teachers/lecturers in our schools and institutions can either stamp out or promote indiscipline amongst physics students. Exploitation of students by lecturers such as compulsory sale of handouts, textbooks, as well as sexual harassment in addition to receiving gratification of all kinds from physics students can promote indiscipline. Moreover, inadequate commitment to duty by teachers and lecturers, incessant industrial actions as well as inadequate incentives and staff welfare policies are also factors that promote indiscipline and unethical behaviours in our tertiary institution.

\section{UNETHICAL PRACTICES IN TERTIARY AND SECONDARY AT THE LEVELS OF PHYSICS EDUCATION}

Unethical practices occur when decisions enable an individual to gain at the expense of the larger society. According to Kanu and Akanwa (2012), unethical practices have affected the fortunes of our educational system and have seriously undermined the quality of physics education in Nigeria. Some unethical practices among physics education teachers that result to physics students' indiscipline in post primary schools and tertiary institutions are:

\section{Promoting malpractice in physics education examination}

Physic examination malpractice according to Okereke
(2012) is securing an undue advantage at physics with a view to achieve an underserved success at any examination in physics. Some physics teachers in post primary schools and tertiary Institutions in Anambra State aid and abet Physics examination malpractice through allowing physics students to bring in course related materials into the physics examination hall, leaking physics examination questions few hours to the examination, granting physics students additional time to finish up, overlooking sundry misdemeanor, preferential physics marking, fraudulent record/allocation of physics marks, physics script substitution after examination (Nwaze, 2011)The effect of this trend on physics students as observed by Ongom (1994) is that it propels dishonesty and lack of integrity.

\section{Indulging in sexual promiscuity in exchange for grades}

Many academics especially young ones ask for sex in exchange of marks (Nwaze, 2011). He also opined that male physics teachers in particular see themselves as thin gods and as such act unprofessional and believe that they will not be caught. When physics academics indulge in sexual promiscuity in exchange for physics grades, physics students tend to have the notion that getting good grades in physics is achieved not through hard work but through sexual affairs with the physics teachers/lecturer, and this undermines the eager spirit of reading to pass physics examination by physics students.

\section{Setting physics examination questions outside the outline}

Setting physics examination question outside the course outline is an unethical practice some physics teachers in post primary schools and tertiary Institutions indulge in. Some physics teachers set tough physics examination questions that are far above the scope of their course outline. According to Kanu and Akanwa (2012) this is a booby trap for physics students to come for sorting. In addition, Anadi et al. (2012), noted that when a physics students switches to sorting mode, he or she trades a commodity for academic favours, and that commodity is primarily money, gift items or sex. This unethical conduct builds in the mindset of physics students the need for putting effort not in studies but in provision of money and gift items in order to pass.

\section{Sale of physics handout and plagiarism}

In some tertiary institutions, physics teachers compel physics students to buy handout and self-published physics textbooks or bear the consequence of failing course. Nwaeze (2011) asserted that text and materials 
sold by physics teachers are largely lifted from seasoned physics textbooks with scanty acknowledgement and improper citation. The compulsion of buying of these physics texts and physics handouts make physics students to centre their learning around the text or handouts as that is the only gateway to excel in the course.

\section{Undertaking to write projects/ thesis for physics students}

A project, thesis or dissertation is a document submitted in support of candidature for an academic degree or professional qualification presenting the author's research and findings (Kanu and Akanwa, 2012). Some physics lecturers in tertiary Institutions undertake to write thesis for their physics students by charging them highly. This causes serious indiscipline on the part of physics students as they do not gear their effort towards research or acquiring knowledge on how research is done, having the notion that a fee can settle the rigorous exercise.

\section{Non-enforcement of attendance to class}

Attendance to lectures/tutorials is an important learning attendance. Kanu and Akanwa in Achukwu and Ementa (2014) noted that one of the crucial factors for physics students' achievement is attendance to class. Some physics teachers do not enforce mandatory attendance to physics class on physics students and this makes physics students to constantly and consistently absent themselves from physics classes.

\section{Lack of commitment to the physics teaching}

Some physics teachers in tertiary institutions are not committed to their physics teaching job. They flagrantly absent themselves from physics classes, delay in marking and release of physics examination results. This lends to demoralize physics students and erupt unruly behavior in them (Ajayi and Adeniji, 2009).

Extortion of money for grades 'sorting', this is an unethical conduct practiced by some physics in tertiary Intuitions in Nigeria. According to Anadi et al. (2012), sorting involves unholy gratifications to a lecturer by a student or group of students for the purpose of getting the lecturer to award, mutilate or illegally change grades of a course or courses in favour of the student or group of students. This only behavior is noted as students collect substantial sum of money from their unsuspecting parents/guardians in the disguise of one university levy or another.

\section{IMPLICATIONS OF UNETHICAL PRACTICES BY TEACHERS AT THE TERTIARY LEVEL OF PHYSICS EDUCATION IN NIGERIA}

A holistic review of ethical issues in our education shows that the sector has received serious battering which has greatly dented its credibility, damaged its image, reduced its effectiveness and has not helped to allow it make the expected impact that it ought to make on character formation, positive lifestyles and the development of our country (Achukwu and Ementa, 2014). It would not be wrong to aver that the moral decadence, depravity, exuberance and turpitude, which seem to pervade the school system, have been vicariously nurtured by the physics teachers and the school system .These are steadily being transmitted into the society of which the physics students and physics teachers are part of and are re-packed to be re-cycled into every facet of our life. On the whole, our value system have been seriously jaundiced, perverted, inflected with gross immorality, circumventing alibis and shore-cats damaging inundated with false pretences, negative life-styles and foul-plays. By way of assessment, can we truly say that our physics students have been found worthy in character and learning to be awarded degree which we normally say when degrees are conferred on them during convocation. The answer is emphatically No! and the ugly situation needs to be addressed.

\section{CONCLUSION}

Teaching is a profession with imbued work ethics and a code of conduct, physics education is a sine qua-non for technological development of the nation. The Teachers' Registrative Council of Nigeria has enunciated a code of conduct that enjoins its members to be exemplary citizens demonstrating integrity, discipline and industry in the development of the profession. As it were most of the unethical practices bedeviling the education sector would have been non-existent, if our physics teachers and other science teachers had keyed into their code of conduct.

As production and circulation of the Teachers Code of conduct guidelines among physics teachers is still very poor in the country, most physics teaches do not have a copy of the Teachers' Code of Conduct Guideline. A good number of physics teachers do not know that such a document exists. Even during their training in tertiary Institutions, enough emphasis is not usually given to physics student teachers on the ethical issues of the profession. Only a few instructors may just mention them in passing, without sufficient display and discussion on the ethical issues of the profession.

Finally, it becomes necessary that physics education teachers should pull resources together and not relent in their efforts to maintain and guarantee discipline as well as promote the habits of discipline and obedience among the physics students of secondary schools and higher institutions. Enforcement of discipline in our Institutions will thus become a means of fulfilling section 1 (5) of the Federal Republic of Nigeria (2012) of National Policy on Education which aims at:

i. The inculcation of national consciousness and national 
unity.

ii. The inculcation of the right type of values and attitudes for the survival of the individual and the Nigeria Society. iii. The training of the mind in the understanding of the world around.

iv. The acquisition of appropriate skill abilities and competencies both mental and physical as equipment for the individual to live in and contribute to the development of his society. This is a task that must be done by all and Sundry so as to move our tertiary Institution forward.

\section{RECOMMENDATION}

Based on the foregoing discussion, the following recommendations were made:

i. Periodic workshops, conferences and seminars are organized for Physics teachers. This will encourage those who have not yet registered with TRCN to do so. It is equally one way to truly give professional status to physics teachers in Nigeria.

ii. Registration and licensing of physics teachers should be done in the teaching Institutions for physics students before graduation. This is done in most of the tertiary Institutions and the practice is quite laudable.

iii. Practicing physics teachers who have not registered and are teaching should be given time frame to register, while those teaching without the necessary qualification should be encouraged to undergo a post graduate diploma programme in physics education from recognized Institutions and be made to register with TRCN. This will produce professionalism and effectiveness among physics teaches.

iv. Also the TRCN should produce and widely circulate the Teachers Code of conduct booklets to all physics teachers in the country.

v. Finally, the physics student-teachers while still in school should be properly instructed on the Teachers Code of conduct like the other professions. One way to achieve this would be to design a course for instruction on Teachers Code of conduct as a compulsory course of study for physics student-teachers in all teaching institutions in Nigeria.

\section{REFERENCES}

Achukwu CB, Ementa CN (2015). Unethical practices among teachers in tertiary Institutions in Nigeria as courses of student's indiscipline. Orient J. Educ. 3(1):50-55.

Ajayi OC, Adeniyi JA (2009). Pursuing Discipline and ethical Issues in Tertiary Institutions in Nigeria. Afr. Res. Rev. 3(1):284-300.

Anadi CC, Egboda PN, Offor IU (2012). Reasons and solutions for the phenomenal increase in sorting in Nigerian Universities: Implication for Global Education. Int. J. Educ. Res. Dev. 4(8):451-464.
Ayee JR (1997). A Code of Ethics for Public Officials, the Ghanaian Experience 1992-16. Int. Rev. Admin. Sci. 63(3):369-375.

Federal Republic of Nigeria (2012). National Policy of Education ( $4^{\text {th }}$ Ed). Abuja: Government Press.

Johnston M (2000). Corruption and Democratic Consideration: Department: Department of Political Science, Hamilton, College University.

Kanu SI, Akanwa UN (2012). Unethical practices in the Nigerian educational system. Interdiscip. J. Contemp. Res. Bus. 4(8):451-464.

Kazeem J, Ige I (2010). Redressing the Growth Concern of the Education Sector in Nigeria. Faculty of Education, University of Benin.

Nwaze C (2011). Corruption in Nigeria explored with cases, scams, laws and preventive measures, Lagos: Control and Associates Limited.

Ogunleye GA (2000). Ethics and Professionalism in Banking: Lessons from the Recent Distress in the Nigerian Banking System. NDIC Quart. J. 10(1).

Okereke C (2012). Perception of students in tertiary Institutions on the causes of examination malpractice. Retrieved from www.agbalifestyle.com.

Olujuwon OT (2004). Transforming the Nigerian System. Retrieved March 29, 2019 from: www.transformed edu.org/conference/parallel/session.

Okpala PN (2014). Professional ethics and innovative practices in Education in the $21^{\text {st }}$ century. Int. J. Educ. Res. Dev. 5(1):7-13.

Ongom DL (1994). Examination Malpractice: causes and effects on the Integrity of education credentials. J. Educ. (1):81-93.

Rogers D (2003). Issues in adolescent psychology (Ed). New York. Meredian co-operation.

Shani FS (2005). Professional ethics and Innovative practices in education in the $21^{\text {st }}$ century. Orient J. Educ. 3(i):26-29.

Surrey Government (2012). Professional Abuse. Retrieved March 29, 2019 from: http://www.surrecc.gov.uk/social-care-and-health/adultsocial-care/protecting-adults-from-harm/adult-abuse-and-differenttypes-of-abuse/professional-abuse.

Teachers Registration Council of Nigeria. (2005). Teachers' Code of conduct Garki Abuja: TRCN.

UhImann EL, Pizarro DA, Tannenbaum D, Ditto PH (2009). The motivated use of moral principles. Judgm. Decis. Mak. 4:476-491.

Zubaida AN (2009). Indiscipline and its management techniques: A case study of a special education school in Kano State. The J. National Council for Excepted Children. 11(2):455-463. 